\title{
Characteristics of Precipitation System Accompanied with Changma Front at Chujado, Korea, in 5 to 6 July 2007
}

\author{
Cheol-Hwan You ${ }^{1}$, Dong-In Lee ${ }^{2}$, Sang-Min Jang ${ }^{2}$, Hiroshi Uyeda ${ }^{3}$, Taro Shinoda ${ }^{3}$, and Fumiaki Kobayashi ${ }^{4}$ \\ ${ }^{1}$ Atmospheric Environmental Research Institute, Pukyong National University, 599-1 Daeyeon 3-Dong Nam-Gu, Busan, \\ 608-737, Korea, Tel: +82-(0)51-629-6639, Fax: +82-(0)51-629-6150 \\ ${ }^{2}$ Department of Environment and Atmospheric Science, PuKyong National University, 599-1, Daeyon-Dong, Nam-Gu, \\ Busan, 608-737, South Korea, Tel: +82-(0)51-629-6639, Fax: +82-(0)51-625-2665 \\ ${ }^{3}$ Hydrospheric Atmospheric Research Center, Nagoya University, Furo-Cho, Chikusa-Ku, Nagoya, 464-8601, Japan, Tel: \\ +81-52-789-3492, Fax: +81-52-789-3436 \\ ${ }^{4}$ Department of Geoscience, National Defence Academy,1-20-20 Hashirimizu Yokosuka, 239-8686, Japan, Tel: \\ +81-46-841-3810, Fax: +81-46-844-5902
}

\begin{abstract}
The rainy season from June to July in the East Asia is called as the Changma in Korea, the Meiyu in China, or the Baiu in Japan. The mesoscale convective systems which occur near a front frequently lead to severe weather phenomenon such as localized gust and heavy rainfall. An intensive field experiment was conducted at Chujado $\left(33.95^{\circ} \mathrm{N}, 126.28^{\circ} \mathrm{E}\right)$ to find out the characteristics of the precipitating system including the rain drop size distribution, kinematic features, and thermodynamics during a Changma period between 21 June 2007 and 11 July 2007. Three identified rainfall cases within the precipitation system caused heavy rainfalls in Chujado for 22 hours and three identified rainfall cases were analyzed using the Doppler radar data, disdrometer data, and sounding data. Based on the radar reflectivity at Chujado, each rainfall system maintained for 7 hours, 4 hours, and 9 hours, respectively. The echo top higher than $30 \mathrm{dBZ}$ was around $6 \mathrm{~km}$ in the two rainfall systems and around $4 \mathrm{~km}$ in the other one. The number concentrations of raindrop has turning point at the drop size of around $2 \mathrm{~mm}$ in diameter. The stronger(weaker) updraft and downdraft cause the decreased number concentration of smaller(larger) size drops and increased that of the larger(smaller) drops. The averaged rain drop size distributions of each rainfall system is well fitted to the gamma distribution. According to the vertical wind shear, the deep warm advection would make rainfall system maintained for longer time and stronger rainrate. Different characteristics of three precipitation cases in a Changma frontal precipitation system were discovered.
\end{abstract}

\section{Introduction}

The rainy season from June to July over the East Asia is referred to the Changma in Korea, the Meiyu in China,

Correspondence to: Dong-In LEE

(leedi@pknu.ac.kr) and the Baiu in Japan. During this period the rainfall area elongated from west to east is called the Meiyu-Baiu front or the Changma front. There have been studies on the frontal heavy precipitation events which sometimes accompany strong wind gusts near those areas (Matsumoto et al., 1971a, b; Akiyama, 1973). The formation of frontal systems is influenced by the moisture transport and convergence of the air mass around the South China Sea (Ninomiya, 1978; Ninomiya and Akiyama, 1992; Lee et al., 1998; Ding and Johnny, 2005).

Several field experiments have been carried out in the East Asia by various organizations of the country at various locations over the region to clarify the structure and evolution of these frontal precipitation systems. In Japan, observation studies of Doppler radars were carried out in Okinawa in 1987, Kyushu Island in 1988, and Kyushu Island and over the East China Sea between 1998 and 2002 (Ishihara et al., 1992, 1995; Takahashi et al., 1996; Yoshizaki et al., 2000). In China, the South China Sea Monsoon Experiment (SCSMEX) was carried out between 1996 and 2001 (Lau et al., 2000; Ding et al., 2004). The purpose of these experiments is to understand the mesoscale feature of frontal systems formed in the East Asia (Moteki et al., 2004). In Taiwan TAMEX (Taiwan Area Mesoscale Experiments) was carried out around Taiwan in 1987 (Lin et al., 1991; Ray et al., 1991; Teng et al., 2000). In Korea, the KORMEX (Korean Mesoscale Experiment) was carried out in the middle of Korean peninsula in 1997 and 1998 (Oh et al., 1997) and the KEOP (Korean Enhanced Observing Program) was carried out in the southern part of Korean peninsula from 2001 to present (Choi and Nam, 2006).

These observational studies are very important especially in Korean peninsula because more than half of annual precipitation over the Korean peninsula is occurred during the summer and a Changma front accompanies a belt-like peak rainfall zone which are developed in the convergence zone between the tropical maritime and continental air mass $(\mathrm{Oh}$ 
et al., 1997). Some heavy rainfall in Korea is developed by mesoscale disturbances in China and then propagates toward east along the frontal system. There have been also many studies on the synoptic conditions of this heavy rainfall (Kim et al., 1983; Lee et al., 1998).

However, the observational studies are focused on the mesoscale features of Changma front and its background field at the southern part of the Korean peninsula have been rarely studied. In order to find out the meso and smaller scale characteristics of the precipitations accompanied by Changma front, the Global Research Laboratory (GRL) of Korean Ministry of Education, Science \& Technology had set an intensive observation period (here after IOP) at Chujado $\left(33.95^{\circ} \mathrm{N}, 126.28^{\circ} \mathrm{E}\right)$ between 21 June 2007 and 11 July 2007 . We identified three separated rainfall systems as the Changma front passes over Chujado within 22 hours and we analyzed each system.

\section{Experiment Setup and Methods}

Several meteorological instruments were installed at Chujado during IOP. The rain gages collected rainfall every $1 \mathrm{~min}$ and radiosonde was launched every $6 \mathrm{~h}$. The Precipitation Occurrence Sensor Systems (POSS) was installed to find out microphysical features of the rainfall system. The surface weather chart, S-band Doppler radars and enhanced IR satellite images from MTSAT were used. Global reanalysis data from NCEP/NCAR were obtained for the synoptic weather conditions of the system. This reanalysis data are composed of $2.5^{\circ} \times 2.5^{\circ}$ grids with 17 vertical levels from $1000 \mathrm{hPa}$ to $10 \mathrm{hPa}$ every $6 \mathrm{~h}$. Observation network covers the southwestern coast of the Korean peninsula and the northern part of the East China Sea with 2 Doppler radars and upper-air soundings (Fig. 1).

To observe the kinematic characteristics of the Changma front dual Doppler radar analysis was carried out using radars at Gosan $\left(33^{\circ} 17 \mathrm{~N} 126^{\circ} 09 \mathrm{E}\right)$ and Seongsan $\left(33^{\circ} 23 \mathrm{~N}\right.$ $\left.126^{\circ} 52 \mathrm{E}\right)$. Those data were interpolated to Cartesian grids using the Sorted Position Radar Interpolation (SPRINT) software (NCAR, 1999) and the Custom Editing and Display of Reduced Information in Cartesian Space (CEDRIC) software package (Miller and Fredrick, 1998). The horizontal and vertical grid resolution was 1.0 and $0.5 \mathrm{~km}$, respectively. Particle fall speeds were estimated from the reflectivity using the same relationship as Biggerstaff and Houze in 1991. And vertical velocity was computed from anelastic equations of continuity using downward integration(O'Brien, 1970) and the echo top was also calculated every 10 minutes for getting an accurate boundary condition. Three components of wind were estimated by dual Doppler analysis using equations presented by Armijo (1969) and Ray et al. (1978 and 1980).

In order to understand the strength of temperature gradient and warm (or cold) advection the total vertical wind shear (here after, TVWS) and directional vertical wind shear (here after, DVWS) were calculated by radiosonde data, respectively (Neiman, 2003). The temperature gradient and the advection are approximated from geostrophic thermal wind equation on the isobaric layer (Holton, 1979). If the geostrophic vertical wind shear is assumed to be realistic, the temperature gradient and the advection can be calculated from the Eqs. (1) and (2). It means that the TVWS is proportional to the strength of the temperature gradient and the positive (negative) DVWS is related to the warm (cold) advection.

$\left|\frac{d \mathrm{~V}}{d z}\right| \equiv \sqrt{\left(\frac{d u}{d z}\right)^{2}+\left(\frac{d v}{d z}\right)^{2}}$

$\frac{d \mathrm{D}}{d z} \equiv-\left(\bar{u} \frac{d v}{d z}-\bar{v} \frac{d u}{d z}\right)$

where, $\quad \mathrm{V}=u \hat{i}+v \hat{j}, \quad \bar{u}=(u(k+1)+u(k-1)) / 2 \bar{v} \quad=$ $(v(k+1)+v(k-1)) / 2, u$ and $v$ are east-west and south-north component of $\mathrm{V}$, respectively, $\hat{i}$ and $\hat{j}$ are unit vector, $k$ is the vertical layer and $d \mathrm{z}$ is $500 \mathrm{~m}$ in this study.

The rain drop size distribution is calculated using the gamma distribution using 3rd, 4th, 6th moments as in Eq. (3) (Ulbrich, 1983; Kozu and Nakamura, 1991):

$N(D)=N_{0} D^{m} \exp (-\Lambda D)$

where, $\quad N_{0}\left(m m^{-1-m} m^{-3}\right), \quad D(m m)$, $m$ (dimensionless), and $\Lambda\left(\mathrm{mm}^{-1}\right)$ represent intercept, diameter of rain drop, shape, and slope, respectively. The DSDs were obtained from POSS which has 34 channels between $0.34 \mathrm{~mm}$ and $5.34 \mathrm{~mm}$.

Daily rainfall amount during IOP was distributed from $8.6 \mathrm{~mm}$ to $92.2 \mathrm{~mm}$. Among these dates, rainfall systems on 5th and 6th July were selected because of its significant rainfall amount. The rainfall at Chujado was caused by Changma and the presence of strong low pressure (Fig. 2). The vertical profile of temporal reflectivity at Chujado area was calculated from Gosan S-band weather radar (Fig. 3). Three different rainfall systems were categorized as follows i.e., (1) the case 1 occurs in 18:00 LT 5 July to 01:00 LT 6 July; (2) the case 2 occurs in 01:00 05:00 LT 6 July, and (3) the case 3 occurs in 05:00 14:00 LT 6 July. The animated weather radar images were used to classify the rainfall system. The systems in case 1, case 2, and case 3 moved from north-west to south-east, west to east and north-west to north-east, respectively(not shown here).

\section{Results}

Enhanced IR images from MTSAT-1R show that the convective cells were located at the south-western of Chujado and moved to north-eastward and south-eastward (Fig. 4). At 23:00 LT 5 July (case 1), rainfall system was located at Chujado and Jeju island. At 03:33 LT 6 July (case 2), there is 
weak rainfall system over Chujado area but convective cells are located at the western part of Chujado. At 06:00 LT (case 3), another convective system approached to Chujado.

The surface weather map shows that southerly wind appears in Chujado area due to the low pressure located at the western part of Jejudo (Fig. 5a). There is convergence over Korean peninsular. In the $850 \mathrm{hPa}$ level, a strong wind higher than $15 \mathrm{~ms}^{-1}$ appears over the whole southern part of Korea (Fig. 5b). The equivalent potential temperature gradient is about $12^{\circ} \mathrm{K}$ in the south-western part of Jejudo. The analysis area is covered with weak positive relative vorticity and the westerly wind is over $15 \mathrm{~ms}^{-1}$ (Fig. 5c). Strong vertical wind shear would occur since westerly wind in upper atmosphere and south-westerly at surface level. Upper level jet passed through Korean peninsula and geopotential height at Chujado is between 9659 and 9700 (gpm) (Fig. 5d).

Dual Doppler analysis using Gosan and Seongsan S-band Doppler weather radars were deployed to understand the general kinematic characteristics of each rainfall system. In case 1 , horizontal convergence occurred in the western part of Chujado. The rainfall system moves into the north-eastern part (Fig. 6a). In the range of 10 to $30 \mathrm{~km}$ of the cross section A-A' in Fig. 6a, both strong updraft and downdraft greater than $\pm 10 \mathrm{~ms}^{-1}$ appear next to each other (Fig. 6b). The echo top of $30 \mathrm{dBZ}$ reaches to nearly $6 \mathrm{~km}$ and the strong south-westerly winds is about $30 \mathrm{~ms}^{-1}$ (Fig. 6c). The convergence are from 10 to $30\left(\times 10^{-4} \mathrm{~s}^{-1}\right)$ and horizontal vorticity is $20\left(\times 10^{-4} \mathrm{~s}^{-1}\right)$ within $20 \mathrm{~km}$ from "A" point (Fig. $\left.6 \mathrm{~d}\right)$. The updraft, convergence, and horizontal vorticity near Chujado were around $5 \mathrm{~ms}^{-1}, 10\left(\times 10^{-4} \mathrm{~s}^{-1}\right)$, and 5 to 15 $\left(\times 10^{-4} \mathrm{~s}^{-1}\right)$, respectively.

In case 2 , the precipitation system with relatively weaker intensity and wind speed than those of case 1 moved into the east (Fig. 7a). The downdraft less than $4 \mathrm{~ms}^{-1}$ was dominated within $20 \mathrm{~km}$ from A as shown in Fig. $7 \mathrm{~b}$. The echo top of $30 \mathrm{dBZ}$ was located around $4 \mathrm{~km}$ and the wind direction with height was almost constant (Fig. 7c). The convergence was not significant and horizontal vorticity was 15 $\left(\times 10^{-4} \mathrm{~s}^{-1}\right)$ within the range of $20 \mathrm{~km}$ from "A" (Fig. 7d). The updraft and horizontal vorticity near Chujado were around $3 \mathrm{~ms}^{-1}$ and -1 to $15\left(\times 10^{-4} \mathrm{~s}^{-1}\right)$, respectively.

In case 3, rainfall system moves to the east or northeastward and strong wind speed reaches greater than $15 \mathrm{~ms}^{-1}$ (Fig. 8a). The downdraft and updraft with 4 to $6 \mathrm{~ms}^{-1}$ occurrs in the range between 40 and $60 \mathrm{~km}$ from "A" and $30 \mathrm{dBZ}$ echo top exists around $6 \mathrm{~km}$ in height (Fig. 8b). In Fig. 8c, south-westerly winds flowed at the surface and higher north-westerly winds than $15 \mathrm{~ms}^{-1}$ flowed at the range of $40 \mathrm{~km}$ from " $\mathrm{A}$ ". The convergence of 10 $\left(\times 10^{-4} \mathrm{~s}^{-1}\right)$ occurs near the $3 \mathrm{~km}$ in height between 40 and $60 \mathrm{~km}$ from "A" (Fig. 8d). The updraft, convergence, and horizontal vorticity near Chujado were around $3 \mathrm{~ms}^{-1}, 10$ $\left(\times 10^{-4} \mathrm{~s}^{-1}\right)$, and -10 to $5\left(\times 10^{-4} \mathrm{~s}^{-1}\right)$, respectively.

Figure 9 shows that the time series of rainrate and number concentration of raindrop with size obtained by POSS. The maximum rainrates for one minute of each case are 113.6, 18.1 and $224.3 \mathrm{mmh}^{-1}$, respectively. The rain drop numbers less than or equal to around $2 \mathrm{~mm}$ and larger than that are very different with cases. Figure 10 shows that the averaged DSDs obtained from a POSS disdrometer and gamma model with cases. The mean rainrate of each case was 6.14 , 2.92, and $9.44 \mathrm{~mm} \mathrm{~h}^{-1}$, respectively. There is significant difference of number concentrations before and after around $2 \mathrm{~mm}$ drop in diameter between case 1 and case 3 . The drops smaller than around $2 \mathrm{~mm}$ in diameter were contributed to case 3 and larger ones than around $2 \mathrm{~mm}$ were contributed to case 1. This tendency is also shown in Fig. 10b. It is considered in simple sense that rain drops in case 1 would be affected by coalescence which decreases the numbers of small size drops and increase those of the larger drops. The DSDs in case 3 would be affected by break-up which increases the numbers of small size drops and decreases the numbers of large size drops. The shapes of each case are 2.14, 2.79, and 0.8 (dimensionless), respectively. This means that measured DSDs from gamma model were different from observed ones especially in smaller size since the smallest drop numbers in the observation are more numbers than those of gamma model. The slopes of each case are 3.72, 4.13, and 3.81 $\left(\mathrm{mm}^{-1}\right)$ and their intercepts are 12469,8679 , and 38248 $\left(\mathrm{mm}^{-1-m} \mathrm{~m}^{-3}\right)$, respectively. Parameters of each gamma fitting are summarized in Table 1.

The air is very humid and there is strong wind shear in the boundary layer below $2 \mathrm{~km}$ through the whole period. The wind speed became stronger with height reaching $20 \mathrm{~ms}^{-1}$ at $4 \mathrm{~km}$. The Lifted Condensation Level (LCL) was $935 \mathrm{hPa}$ and the K-Index value which represent the convective potential was 36 (Fig. 11a). At 03:00 LT 6 July, the wind veered from north-easterly to westerly or north-westerly below $4 \mathrm{~km}$ and the wind speed was constant below $1 \mathrm{~km}$ and became stronger from $1 \mathrm{~km}$ to $3 \mathrm{~km}$ with height. The LCL was $927 \mathrm{hPa}$ and the value of K-Index was 40 (Fig. 11b). In case 3 , the wind speed at the surface was around $10 \mathrm{~ms}^{-1}$ and increased with height below $2 \mathrm{~km}$. All the layers below $8 \mathrm{~km}$ in height were humid with relative humidity larger than $80 \%$ and the radio sonde moved up and down in the height of $4 \sim 6 \mathrm{~km}$ because of the strong downdraft. The LCL was $951 \mathrm{hPa}$ and the value of K-Index was 36 (Fig. 11c).

Figure 12 shows the TVWS and DVWS obtained from radio sondes for case 1,2, and case 3 . The TVWS is the highest at the lower level and decreased with height. The high TVWS at case 2 is due to the presence of the lower level jet. The DVWSs were -3.3 degrees $/ \mathrm{km}, 68.2$ degrees $/ \mathrm{km}$, -40.1 degrees $/ \mathrm{km}$, and 41.2 degrees $/ \mathrm{km}$ at $1 \mathrm{~km}, 2 \mathrm{~km}, 3 \mathrm{~km}$ and $4 \mathrm{~km}$, respectively. It means that the cold (warm) advection appeared at $1 \mathrm{~km}$ and $3 \mathrm{~km}(2 \mathrm{~km}$ and higher than $4 \mathrm{~km})$. In case 2, the DVWS was 20.9 degrees $/ \mathrm{km}$ at $1 \mathrm{~km},-11.2$ degrees $/ \mathrm{km}$ at $2 \mathrm{~km}$, and 186.9 degrees $/ \mathrm{km}$ at $3 \mathrm{~km}$. It means that the warm (cold) advection dominated at the height of $1 \mathrm{~km}, 3 \mathrm{~km}, 4 \mathrm{~km}$ and $5 \mathrm{~km}(2 \mathrm{~km}$ and $6 \mathrm{~km})$. In case 3 , the DVWS was 108.2 degrees $/ \mathrm{km}$ at the height of $1 \mathrm{~km}$ and the 
positive DVWS dominated in the whole layer which means the warm advection was significant at all layers.

\section{Concluding remarks}

To understand characteristics of precipitation system accompanied with Changma front, three rainfall cases within one precipitation system were identified and analyzed by using Doppler radar data, disdrometer data and radio sonde data. The schematic view of precipitation system accompanied by Changma front from 5 to 6 July in 2007 is shown in Fig. 13. These three rainfall cases caused by one precipitation system in a view of synoptic scale but we found out that there are different characteristics.

The echo top higher than $30 \mathrm{dBZ}$ was around $6 \mathrm{~km}$ in case 1 and case 3 . However, the number concentrations of raindrop has turning point at the drop size of around $2 \mathrm{~mm}$ in diameter. The stronger(weaker) updraft and downdraft cause the decreased number concentration of smaller(larger) size drops and increased that of the larger(smaller) drops. According to the results of vertical wind shear, the deep warm advection would make rainfall system maintained for longer time and stronger rain rate but smaller size diameter of raindrop. And the averaged rain drop size distributions of each rainfall system is well fitted to the gamma distribution

In this study, the smaller scale rainfall systems and few cases were focused. In the future, the characteristics of mesoscale precipitation system will be further investigated by analyzing the system for shorter time and focusing on the precipitation appearance like band shape type with its orientation as it is propagating.

Acknowledgements. This work was supported by the Korea Foundation for International Cooperation of Science \& Technology(KICOS) through a grant provided by the Korean Ministry of Education, Science \& Technology (MEST) in 2008 (No. K2 0607010001-08A050100110) and partly supported by the second stage of BK21 Project of the Graduate School of Earth Environmental System. We thank to the Korean Meteorological Administration for providing data and the National Center for Environmental Protection for the reanalysis data.

\section{References}

Armijo, L.: A theory for the determination of wind and precipitation velocities with Doppler radars, J. Atmos. Sci., 26, 570-575, 1969.

Akiyama, T.: The large-scale aspects of the characteristics features of the Baiu front, Pap. Meteor. Geophy., 24, 157-188, 1973.

Biggerstaff, M. I. and Houze Jr., R. A.: Kinematic and precipitation structure of the 10-11 June, 1985 squall line, Mon. Wea. Rev., 119, 3034-3065, 1991.

Choi, Y. J. and Nam, J. C.: Introduction of phase I KEOP, Proceedings of the spring meeting of KMS, 384-385 (In Korean), 2006.

Ding, Y. H., Li, C. Y., and Liu, Y. J.: Overview of the South China Sea monsoon experiment, Adv. Atmos. Sci., 21, 343-360, 2004.
Ding, Y. H. and Johnny, C. L. C.: The East Asian summer monsoon: and overview, Meteor. Atmos. Phys., 89, 117-142, 2005.

Holton, J. R.: An introduction to dynamic meteorology: Academic Press, California, United States of America, 391 pp, 1979.

Ishihara, M., Tabata , A., Akaeda, K., Yokoyama, T., and Sakakibara, H.: The structure of a subtropical squall line observed with a Doppler radar, Tenki, 39, 727-743 (in Japanese), 1992.

Ishihara, M., Fujiyoshi, Y., Tabata, A., Sakakibara, H., Akaeda, K., and Okamura, H.: Dual Doppler radar analysis of an intense mesoscale rainband generated along the Baiu front in 1988: Its kinematical structure and maintenance process, J. Meteor. Soc. Japan, 73, 139-163, 1995.

Kim, S. S., Chung, C. H., Park, S. U., and Lee, B. S.: The characteristic structural differences of the rainy front (Changma front) between the wet and dry seasons, J. Korean Meteor. Soc., 19, 12-32 (in Korean), 1983.

Kozu, T. and Nakamura, K.: Rainfall parameter estimation from dual-radar measurements combining reflectivity profile and pathintegrated attenuation, J. Atmos. Oceanic Technol., 8, 259-271, 1991.

Lau, K. M., Ding, Y. H., Wang, J. T., Johnson, R., Cifelli, R., Gerlach, J., Thjiely, O., Rikebbach, T., Tsay, S. C., and Lin, P. H.: A report of the field operation and early results of the South China Sea monsoon experiment (SCSMEX), Bull. Amer. Meteor. Soc., 81, 1261-1270, 2000.

Lee, D. K., Kim, H. R., and Hong, S. Y.: Heavy rainfall over Korea during 1980-1990, Kor. J. of Atmos. Sci., 1, 32-50, 1998.

Lin, Y. J., Pasken, R.W., and Chang, H. W.: The structure of a subtropical prefrontal convective rainband. Part I: Mesoscale kinematic structure determined from dual Doppler measurements, Mon. Wea. Rev., 120, 1816-1836, 1991.

Miller, L. J. and Fredric, S. M.: Custom Editing and Display of Reduced Information in Cartesian space (CEDRIC) manual, National Center for Atmospheric Research, Colorado, United States of America, 130 pp, 1998.

Moteki, Q., Uyeda, H., Maesaka, T., Shinoda, T., Yoshizaki, M., and Kato, T.: Structure and development of two merged rainbands observed over the East China Sea during X-BAIU-99 PART I: Meso- $\beta$-scale structure and development processes, J. Meteor. Soc. Japan, 82, 19-24, 2004.

NCAR: Sorted Position Radar Interpolation (SPRINT) manual, National Center for Atmospheric Research, Colorado, United States of America, 76 pp, 1999.

Matsumoto, S., Yoshizumi, S., and Takeuchi, M.: Characteristic feature of Baiu front associated with heavy rainfall, J. Meteor. Soc. Japan, 49, 267-281, 1971a.

Matsumoto, S., Yoshizumi, S., and Takeuchi, M.: On the structure of the "Baiu Front" and the associated intermediate scale disturbances in the lower atmosphere, J. Meteor. Soc. Japan, 48, 479-491, 1971b.

Nieman, P. J.: Private communication, 2003.

Ninomiya, K.: Heavy rainfalls associated with frontal depression in Asia subtropical humid region. PART I: Synoptic-scale features, J. Meteor. Soc. Japan, 56, 253-266, 1978.

Ninomiya, K. and Akiyama, T.: Multi-scale features of Baiu, the Summer Monsoon over Japan and East Asia, J. Meteor. Soc. Japan, 70, 467-495, 1992.

O'Brien, J. J.: Alternative solution to the classical vertical velocity problem, J. Appl. Meteor., 9, 197-203, 1970. 
Oh, J. H., Kwon, W.T., and Ryoo, S.B.: Review of the researches on Changma and future observational study (KORMEX), Adv. Atmos. Sci., 14, 207-222, 1997.

Ray, P. S., Wagner, K. K., Johnson, K.W., Stephens, J.J., Bumgarner, W.C., and Mueller, E.A.: Triple-Doppler observations of a convective storm, J. Appl. Meteor., 17, 1201-1212, 1978.

Ray, P. S., Ziegler, C. L., Bumgarner, W., and Serafin, R.J.: Singleand multiple-Doppler radar observations of tornadic storms, Mon. Wea. Rev., 108, 1607-1625, 1980.

Ray, P. S., Robinson, A., and Lin, Y.: Radar analysis of a TAMEX frontal system, Mon. Wea. Rev., 119, 2519-2539, 1991.

Takahashi, N., Uyeda, H., Kikuchi, K., and Iwanami, K.: Mesoscale and convective scale features of heavy rainfall events in lat period of the Baiu season in July 1988, Nagasaki Prefecture, J. Meteor. Soc. Japan, 74, 539-561, 1996.

Teng, J. H., Chen, C. S., Wang, T. C. C., and Chen, Y. L.: Orographic effects on a squall line system over Taiwan, Mon. Wea. Rev., 128, 1123-1138, 2000.

Ulbrich, C. W.: Natural variations in the analytical form of the raindrop size distribution, J. Climate Appl. Meteor., 22, 1764-1775, 1983.

Yoshizaki, M., Kato, T., Tanaka, Y., Takayama, H., Shoji, Y., Seko, H., Arao, K., Manabe, K., and Members of X-BAIU-98 Observation: Analytical and numerical study of the 26 June 1998 orographic rainband observed in Western Kyushu, Japan, J. Meteor. Soc. Japan, 78, 835-856, 2000. 


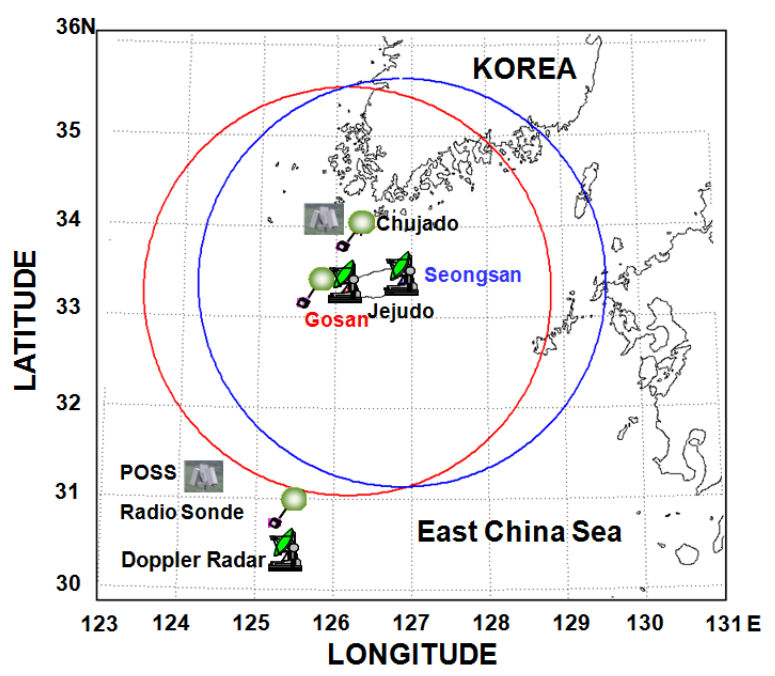

Fig. 1. The location of Doppler weather radar and radiosonde launched. The circle with $250 \mathrm{~km}$ in radius shows the Doppler radar analysis area.

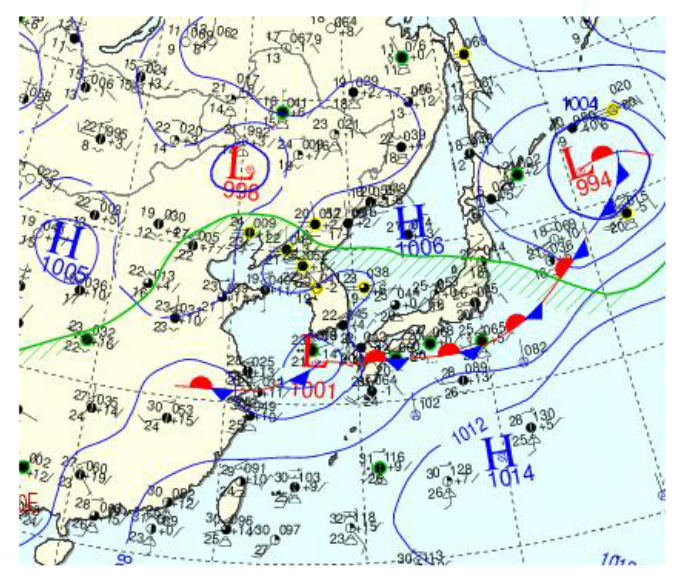

Fig. 2. The surface weather chart on 09:00 LT 6 July 2007.

Table 1. The characteristics of each case obtained from DSDs.

\begin{tabular}{cclc}
\hline & CASE 1 & CASE 2 & CASE 3 \\
\hline Shape, $\Lambda\left(\mathrm{mm}^{-1}\right)$ & 2.14 & 2.79 & 0.8 \\
Slope $\left.m^{-1-m} m^{-3}\right)$ & 3.72 & 4.13 & 3.81 \\
Intercept, $N_{0}\left(m^{-169}\right.$ & 8,679 & 38,248 \\
Sample No. & 402 & 171 & 485 \\
\hline
\end{tabular}

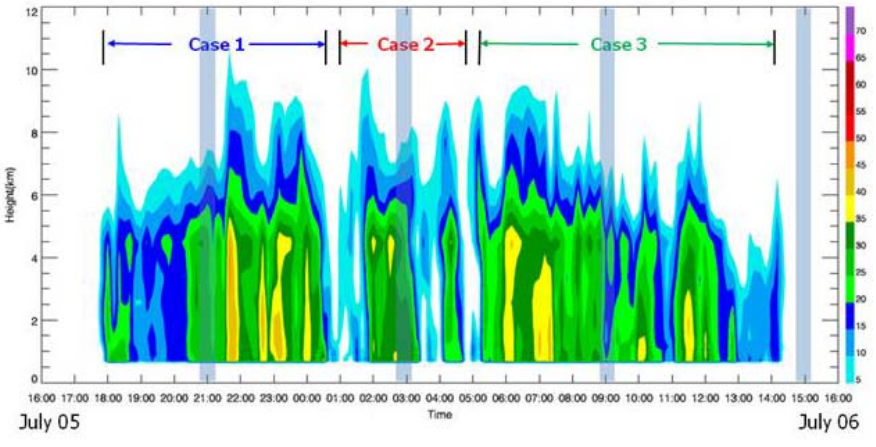

Fig. 3. The vertical profile of temporal reflectivity with time at Chujado from Gosan weather radar. Blue shaded boxes show the time radiosondes launched.

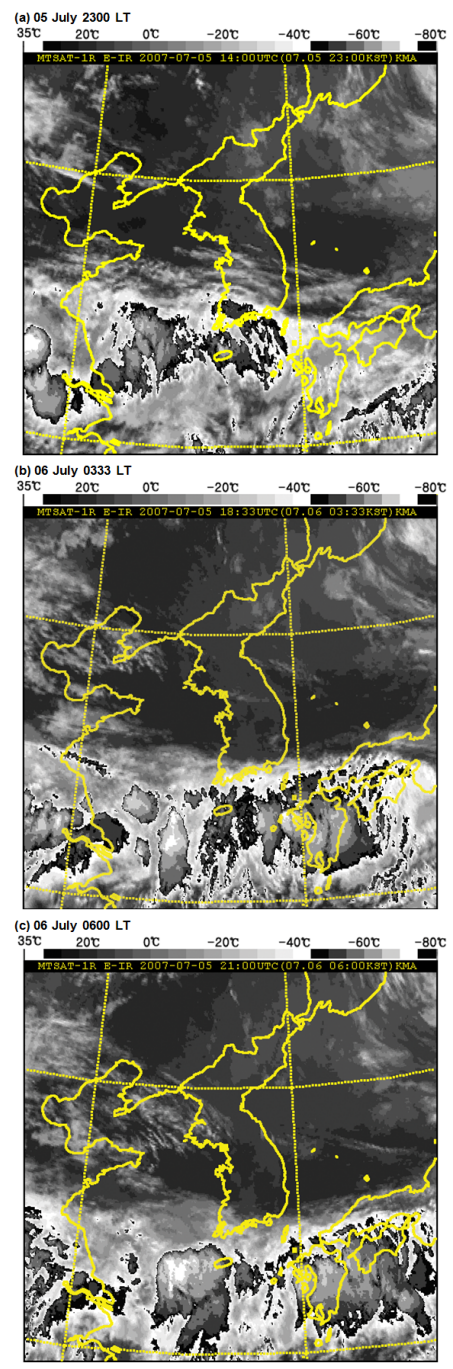

Fig. 4. Enhanced IR images of MTSAT-IR from 23:00 LT 5 July to 11:00 LT 6 July, 2007. 

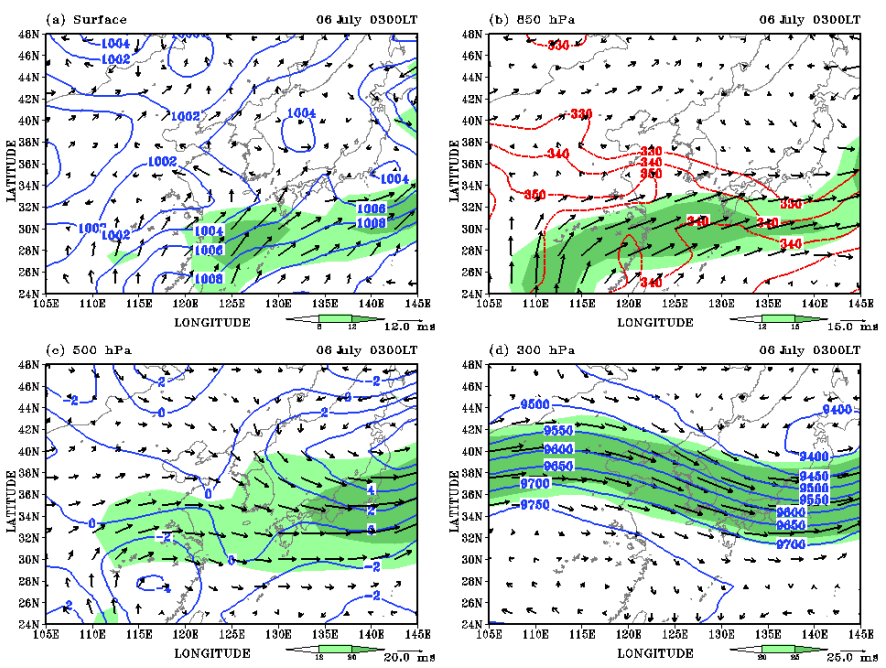

Fig. 5. (a) Pressure and wind vector at surface, (b) equivalent potential temperature and wind vector at $850 \mathrm{hPa}$, (c) relative vorticity and wind vector at $500 \mathrm{hPa}$, (d) geopotential height and wind vector at 300 hPa at 03:00 LT 6 July 2007.
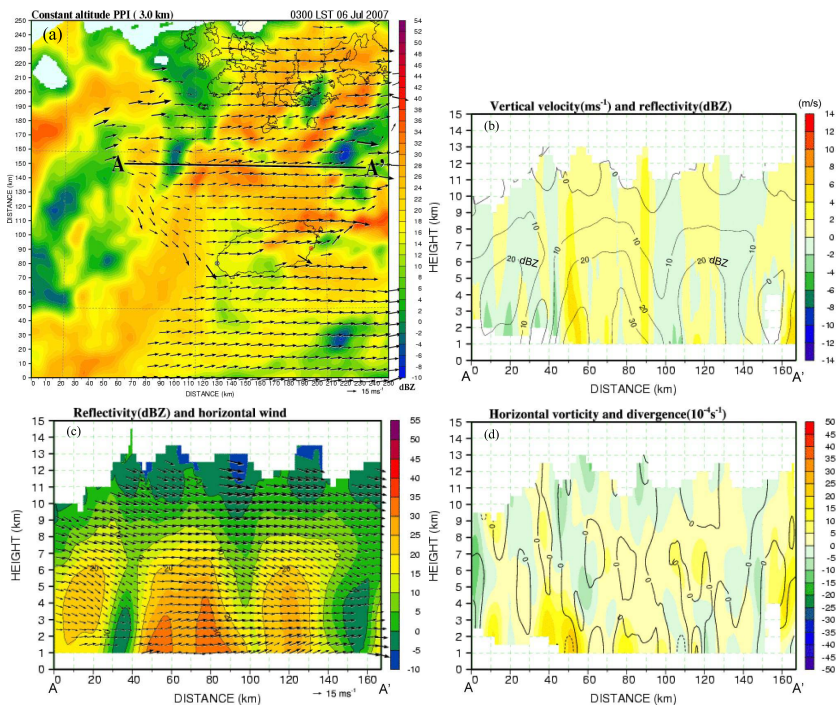

Fig. 7. Same as Fig. 8 but for 03:00 LT 6 July.
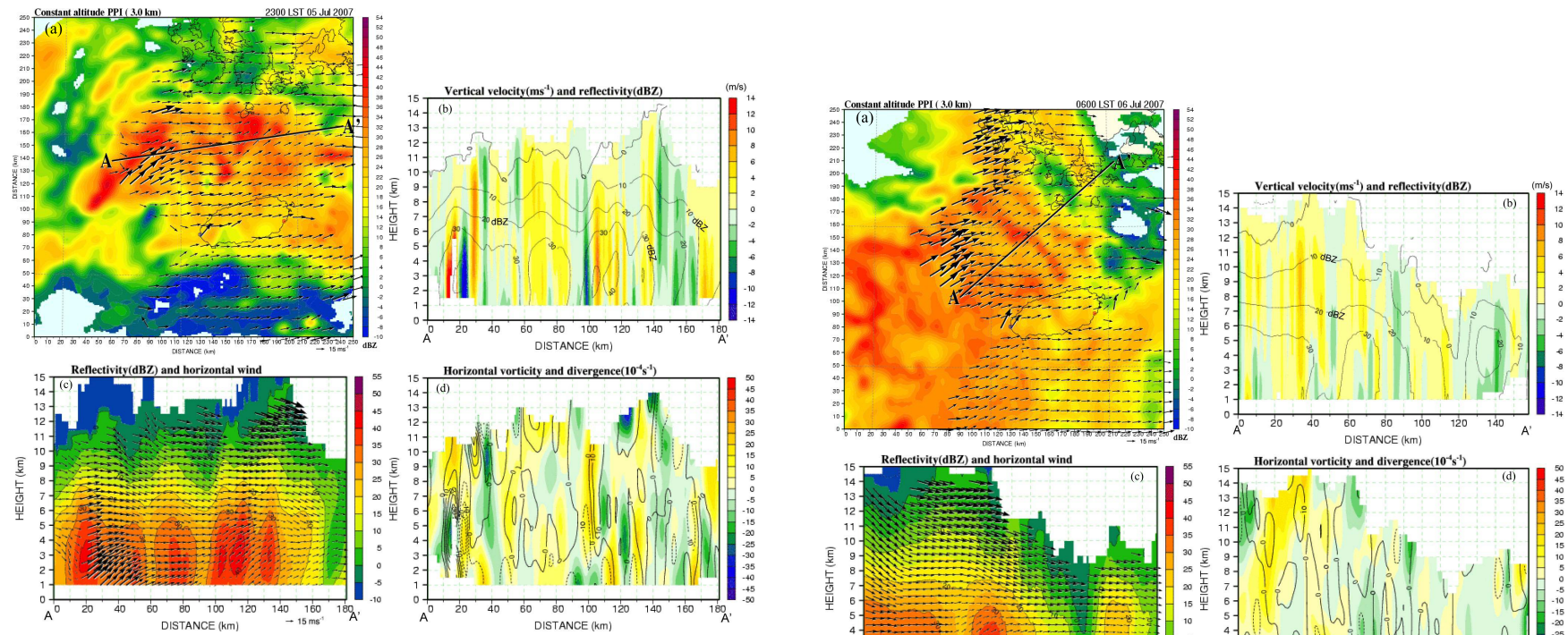

Fig. 6. (a) The reflectivity and horizontal wind field at the $3 \mathrm{~km}$ CAPPI at 23:00 LT 5 July 2007. Vertical cross sections along A-A' (b) vertical velocity and reflectivity (contour), (c) horizontal wind and reflectivity, and (d) horizontal vorticity and divergence (contour).
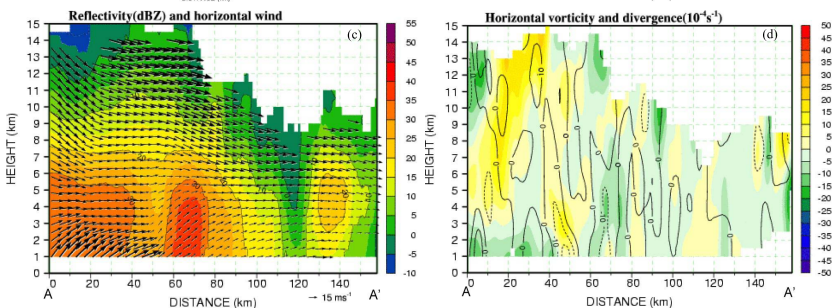

Fig. 8. Same as Fig. 8 but for 06:00 LT 6 July. 

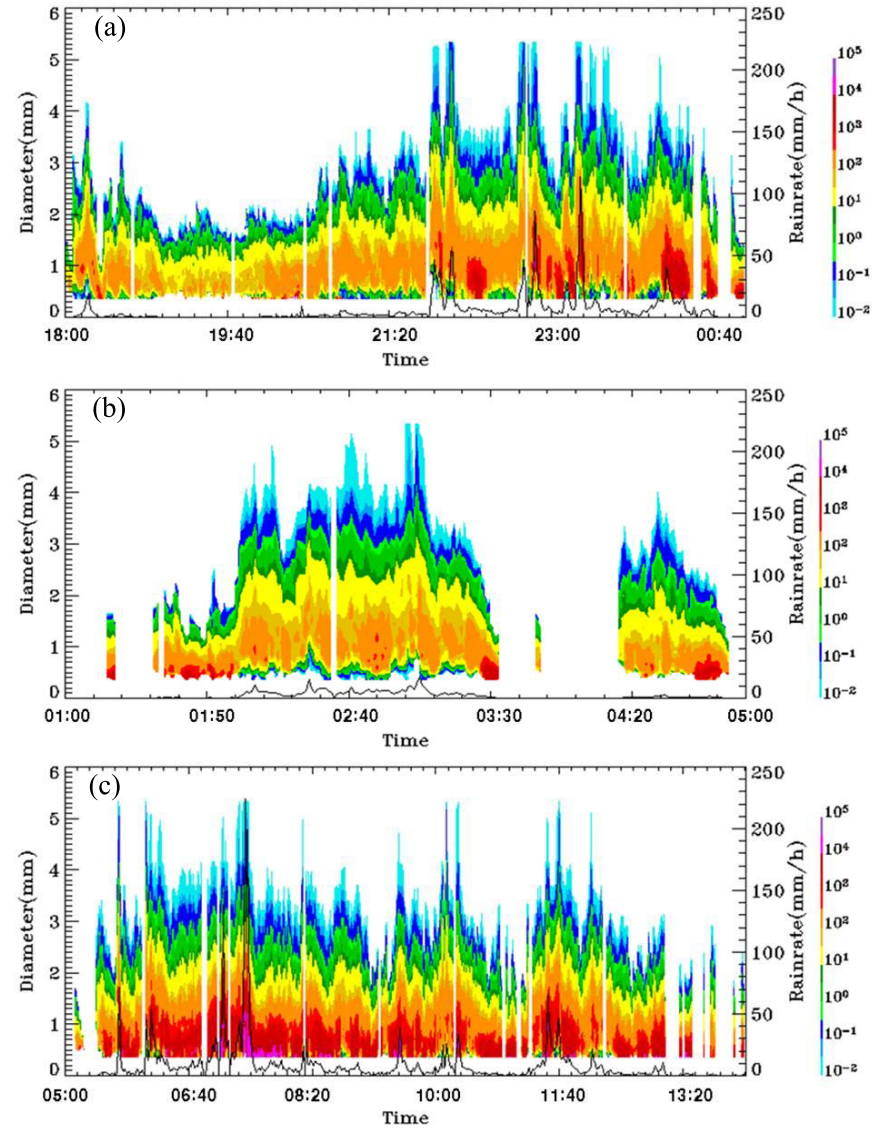

Fig. 9. The time series of rain drop size (left axis) and rainrate (right axis) derived from POSS (a) case 1 , (b) case 2 , and (c) case 3 . The color scale means number concentration of rain drop and solid line is rainrate.
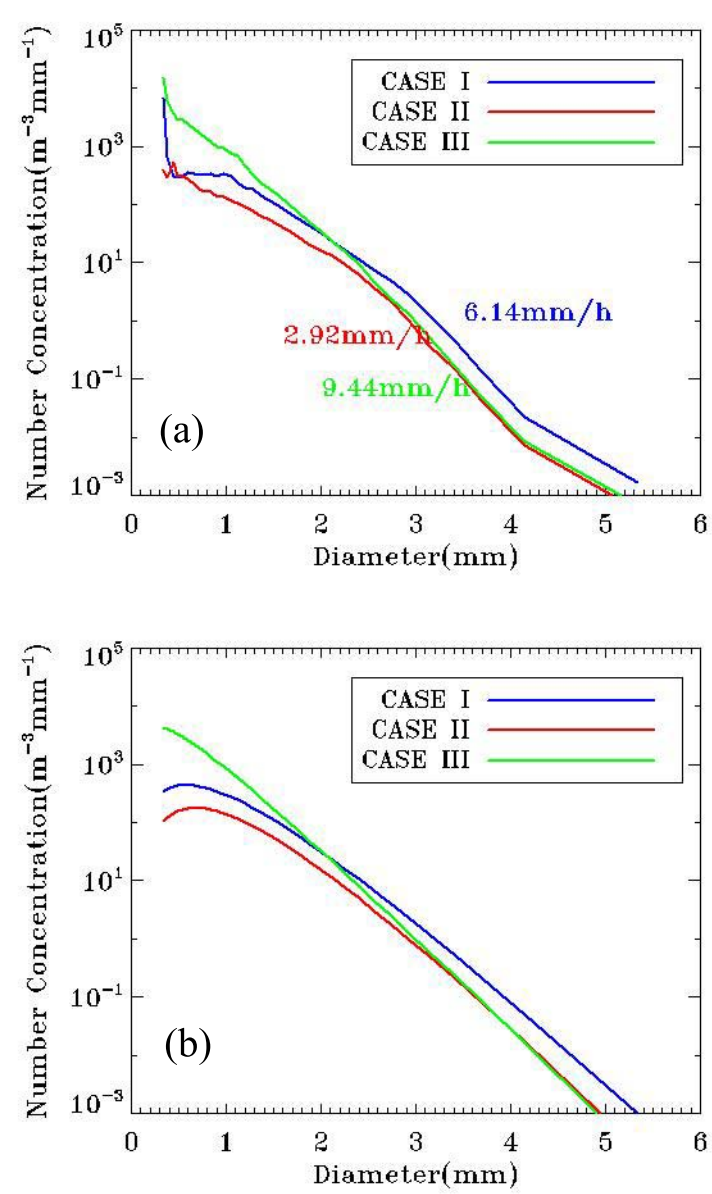

Fig. 10. Averaged DSD from (a) POSS disdrometer and (b) gamma distribution. 


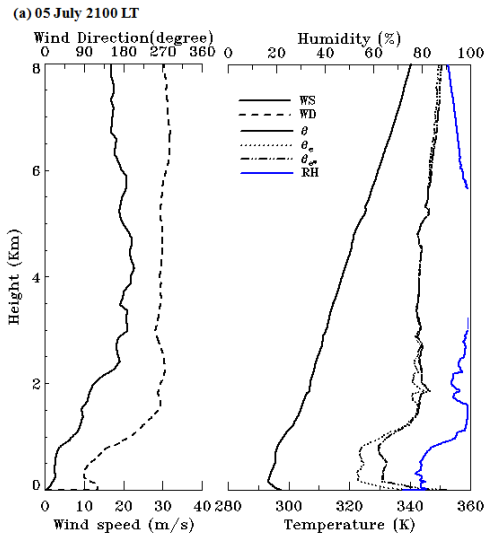

(b) 06 July $0300 \mathrm{LT}$

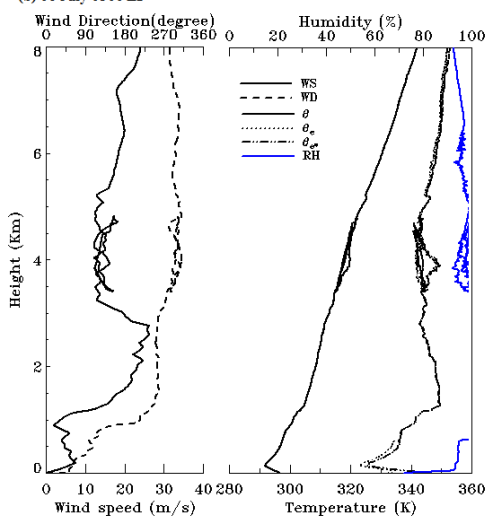
(c) 06 July $0900 \mathrm{LT}$

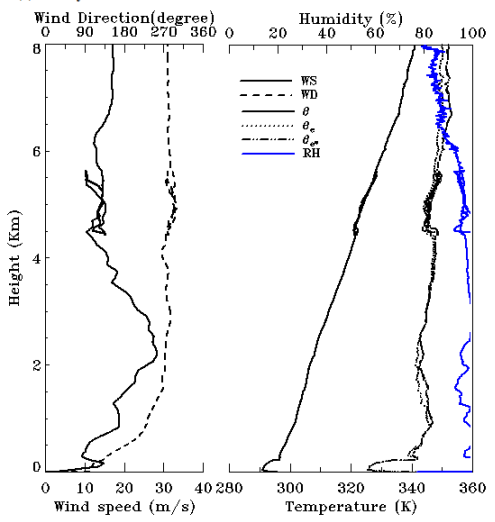

Fig. 11. The vertical profiles of wind speed, wind direction, potential temperature $\theta$, equivalent potential temperature $\theta \mathrm{e}$, saturated equivalent potential temperature $\theta_{e *}$, and relative humidity from radio sonde.
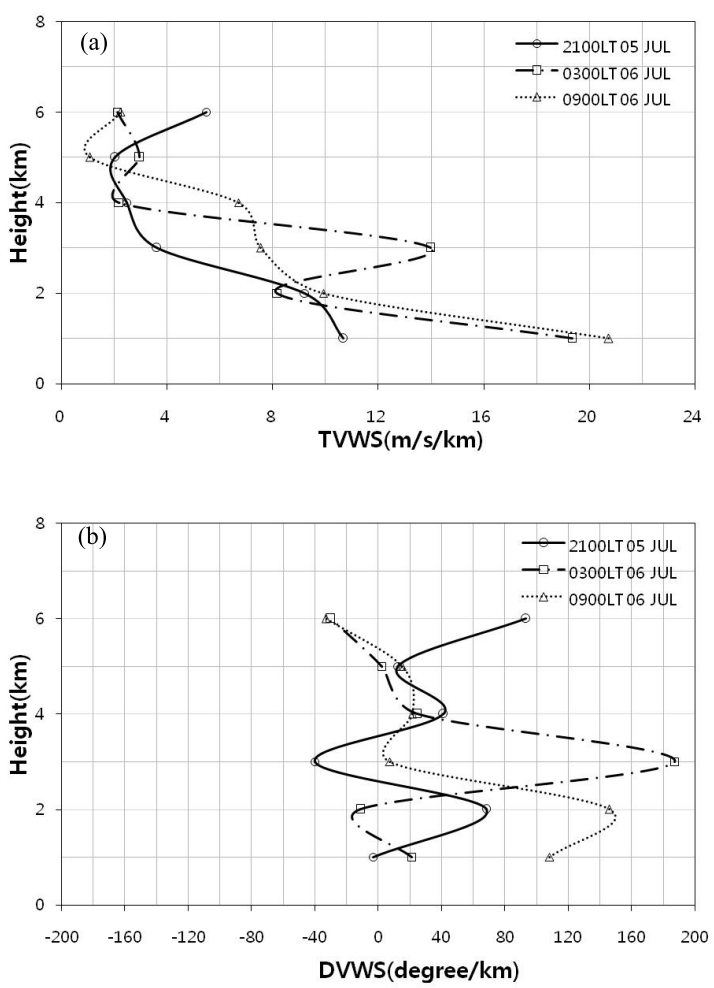

Fig. 12. The total vertical wind shear (TVWS, a) and directional vertical wind shear (DVWS, b) obtained from radio sonde.

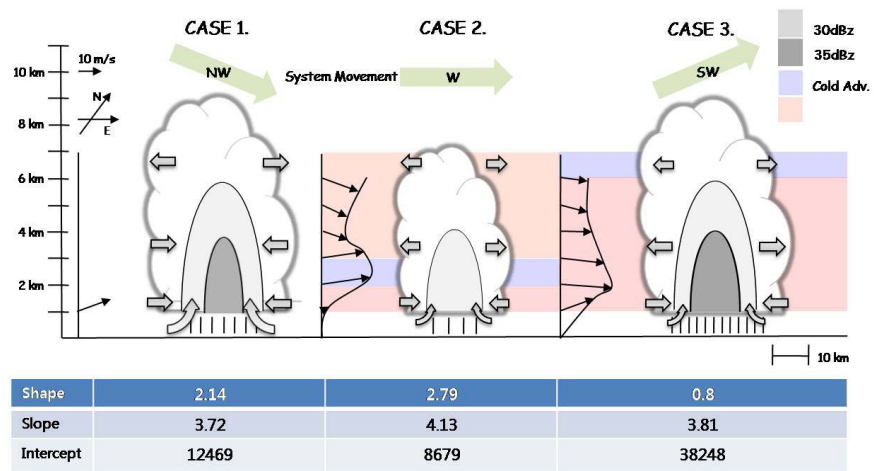

Fig. 13. Schematic diagram and gamma parameters of three identified rainfall systems of the observed Changma front. 